\title{
AFRICAN ENTREPRENEURSHIP AND INNOVATION FOR SUSTAINABLE DEVELOPMENT: INTRODUCTION TO THE SPECIAL ISSUE
}

\author{
Nnamdi O. Madichie \\ Nnamdi Azikiwe University, Awka
}

It gives me great pleasure to put together this Special Issue following the successful conclusion of the 2017 International Conference on "African Entrepreneurship and Innovation for Sustainable Development (AEISD)," which was hosted by Nnamdi Azikiwe University, Awka, Nigeria. The conference sought to bridge the gap between entrepreneurial policy and actionable entrepreneurship for Africa's economic development. The conference theme "The Promise of Actionable Entrepreneurship for Sustainable Economic Development in Africa: Leadership, Governance, and Ethics," says a lot about the conversations selected for this special issue.

The need to establish accessible pathways for sustainable entrepreneurship success and wealth creation to alleviate chronic poverty in Africa in general and Nigeria in particular, is rather pertinent. Focus areas of the conference included government policies to promote entrepreneurship, access to finance, education and training, commercial and professional infrastructure, openness of internal markets, physical infrastructure, and the Triple-Helix of University-Industry-Government Partnerships. The conference also solicited actual case studies of entrepreneurship and success stories in entrepreneurship from other parts of the world - albeit with implications for African development.

The conference received over 40 papers from scholars, entrepreneurs, graduate students, managers and policy makers on entrepreneurship and innovation issues pertinent to a vibrant and sustainable economic development of Africa. From the papers presented at the conference, a selection of peer reviewed manuscripts was considered for publication in this special issue dedicated to that successful conference.

Overall, the following contributions, while not necessarily exhaustive in their coverage of the conference theme or discussions at the event at the time, nonetheless pave the way for further deliberations on the topic. It is my pleasure, therefore, as editor-in-chief to provide our readers with a sample of the conversations about African development (Nigeria or otherwise), which need continuous updating as the continent surges onwards and upwards. This issue of the second consecutive volume of the Unizik Journal of Business, forms part of the University's contribution to the development of the region as further global economic events unfold in our march to another milestone enshrined in the 2030 vision embraced by most countries across the globe.

In the first paper Idemobi \& Ofili, sought to ascertain the effect of credit delivery on the growth of the agricultural sector in the Nigerian economy, and to highlight what this means for entrepreneurship development in that country. Their main preoccupation was to ascertain the effect of credit facilities for cash crop production on the agricultural sector - a key source of employment. They also sought to determine the effect of credit facilities for livestock production on the growth of the agricultural sector' as well as the extent to which credit facilities for fisheries affect that sector of the economy. In their findings, these authors revealed that that credit delivery for livestock farming had a positive and significant effect on the growth of the agricultural sector. They argued that while credit facilities on cash crop farming shows a negative effect on the growth of agricultural sector, that of fish farming has no significant 
effect on the growth of the sector. This has some serious managerial and policy implications going forward.

In the second paper, Okerekeoti \& Okoye, argue that "successive governments in Nigeria have continued to operate multiple accounts for the collection and disbursing of government revenues in flagrant disregard to the provision of the constitution which requires that all government revenues be remitted into a single account." Drawing insights from the Treasury Single Account (TSA), the authors described this initiative as "a quick fix to regulating the level of accountability and transparency in the financial resources of the government of the country." According to them, the TSA - an arguably "unified structure of government bank accounts enabling consolidation and optimal utilization of government cash resources," warranted further interrogation. To wrap up the authors called upon the government to undertake an overhaul of the capacity of the Federal Ministry of Finance and the Apex Bank to tackle the challenges associated with enforcement of the provisions under the TSA.

In the third paper, Idemobi \& Onukwuli state that "African entrepreneurs must embrace entrepreneurs' environmental management competencies as part of a strategic focus for crosscultural management." These authors describe their study as an examination of the entrepreneurial environment and cross-cultural management as a road map of sustaining African development. It is worth highlighting the keywords here - sustainable African development. What this seems to suggest, is that the study converges on Africa meeting the sustainable development goals or SDGs. In order to assess the progress made thus far (i.e., as at 2017), the authors explored the relationship between entrepreneurial environment and crosscultural management. They also examined why cross-cultural orientation was of importance to African entrepreneurs; and to determine the effect of globalization on entrepreneurial environment and cross-cultural management. The study ultimately argued, and posited (with a proposed model as evidence) that entrepreneurial culture, environmental turbulence and global network competencies improve the relationship between entrepreneurial environment and cross-cultural management.

Jiboye et al., in the fourth paper, postulated that studies have affirmed that restructuring for sustainable development is a process involving three essential elements - feasible industrial growth to fulfil basic socio-economic needs, ensuring maximum development of human resources and achieving greater social justice through a more equitable income distribution. According to them, "none of these is satisfactorily manifesting in African nations." With the high unemployment rate, especially among the youth and young graduates in the country, these authors were on to making an important contribution for management and policy. The study examined the contributions of cooperative societies, working in partnership with universities, on poverty eradication projects. This obviously speaks to Goals $1 \& 2$ of the United Nations' Sustainable Development Goals or SDGs. Although the study was based on 2972 respondents from 1486 cooperative societies in a single part of the country, Osun State, the implications could be explored nationwide. From the results of the study, it seemed persuasive that cooperative societies had the ability to make significant economic contributions to society cutting across key areas such as job creation, income generation, poverty reduction, environmental sustainability, and institutional capacity building.

In the fifth paper, Okoro \& Okoye point out that "since the 2004 Pension Reform Act, pension schemes have manifested in twofold: 'old' and 'new'. The Pension Act No. 102 of 1979 is the "old pension" (non-contributory) and Pension Reform Act of 2004 (including the 
restructured/modified Pension Act, 2014) is the "new pension" (contributory) scheme." These authors comparatively evaluated both the non-contributory (pre) and contributory (post) pension schemes in Nigeria drawing upon secondary data of pension investment funds covering a 20-year period covering 1994 to 2014. Based on the analysis of data, they report that the 'post' scheme was healthy, reliable and poised towards helping retirees survive post-retirement. Thus, the contributory (post) scheme significantly improved as a result of the reform in Nigeria, especially in the area of pension investment funds. These authors went on to recommended that, among other measures, there needed to be an unrestricted retirement savings scheme and non-remittance of pension contributions by employers to the Pensions Commission (PENCOM). The also called for the improvement of internal procedures that would ensure efficient and timely contributions and returns on pension investments, upon retirement, from pension fund administrators.

In the sixth and final paper, Ezeh \& Nkamnebe explored entrepreneurial intentions of undergraduate students in Federal University, Gusau in the Northwest of the country. Drawing insights from the theory of planned behaviour, and empirically tested on a sample of 200 higher institution students in Zamfara State, the authors report that entrepreneurial intention served as a function of subjective norm and perceived behavioural control. The study compared the entrepreneurial intention of Hausas and Igbos, and concluded that the latter ethnic group was more entrepreneurial - even with the geographic enclave of the former. This revelation has some real policy implications for both policy makers and educators alike.

Overall, the papers in this issue have touched upon rather pertinent topics - from the impact of credit delivery on the growth of the agricultural sector; to the collection and disbursing of government revenues in flagrant disregard to the provision of the constitution which requires that all government revenues be remitted into a single account - drawing insights from the Treasury Single Account initiative. They have also, to some extent, examined the entrepreneurial environment and cross-cultural management as a road map of sustaining African development. There were also suggestions on the need for African entrepreneurs to embrace environmental management competencies in line with the principles of the SDGs. Indeed, that conversation continues with a call for restructuring to tackle three essential elements - feasible industrial growth to fulfil basic socio-economic needs; ensuring maximum development of human resources; and achieving greater social justice through a more equitable income distribution. One of the contributions in this issue points to the 2004 Pension Reform Act and the debate over 'old' and 'new' pension notably replacing the non-contributory Pension Act No.102 of 1979 with a contributory scheme. Finally, with the topic of pension reforms touching the goal of decent work (SDG 8), there was also some insight among the entrepreneurial intentions of the huge youth population.

In summing up, I would like to take this opportunity to thank and recognise everyone who played a part in the success of this timeless gathering, and consequent emergence of this special issue.

Starting with overseas partners, my gratitude goes out to Professor Alphonso Ogbuehi, Programme Chair and Professor of Marketing at the Clayton State University, as well as US Fulbright Visiting Professor at the Nnamdi Azikiwe University. Others include Professor Avi Mukherjee, Dean, College of Business, Clayton State University, USA, and Prof. Lou Jourdan, Director, Center for Entrepreneurship \& Innovation, Clayton State University, USA. Further thanks go out to the conference Track Chairs \& Co-Chairs including the likes of Professor 
Norma Juma of Washburn University USA, Professor Chris Enyinda of the Canadian University of Dubai, UAE, and Dr. Gbola Gbadamosi of Bournemouth University, United Kingdom, who served as Track Chair for Graduate Student Papers.

At the local level thanks for the diligent work of Professor Anayo Nkamnebe, Dean, Faculty of Management Sciences, Nnamdi Azikiwe University, Professor Emma Okoye, Dr. Jude Onyima, Professor M.C. Muo, Prof. C.C. Okolocha, Dr. Titus Okeke, Dr. Hope N. Nzewi, Dr. C. Y. Ogbodo, Dr. Mary Chiekezie, and Dr. Gideon Ezu who served as Conference Secretary - all of the Nnamdi Azikiwe University.

Last, but surely not least, I would also like to put on record the contribution of Chief Uche Nworah, MD/CEO, Anambra Broadcasting Service (ABS), Awka - Media Partner. 